\title{
ウォーターインソールによる歩行前後の足部血流の変化
}

\section{The Increase in Skin Blood Flow while Walking with Wearing Water Insole}

\author{
○入澤 寛 ${ }^{1}$ ，美津島 隆 ${ }^{1}$, 山内 克哉 ${ }^{1}$ ，安田 千里 ${ }^{1}$, 森田 信義 ${ }^{2}$ \\ 1. 浜松医科大学附属病院リハビリテーション科, 2. 静岡大学工学部
}

OHiroshi IRISAWA ${ }^{1}$, Takashi MIZUSHIMA ${ }^{1}$, Katsuya YAMAUCHI ${ }^{1}$, Chisato YASUDA ${ }^{1}$, and Nobuyoshi MORITA ${ }^{2}$

1. Hamamatsu University School of medicine, 2. Shizuoka University

\begin{abstract}
1. 目的
ウォーターインソールは静岡大学工学部で開発されたインソー ル(靴の中敷き)であり, インソール内に水とその流れをコントロー ルする堰とオリフィスで構成されている. 2005 年の本学会で衝撃 吸収効果 1), 2007 年の本学会で座位での血流増加効果 2)につ いて報告した.今回我々はウォーターインソール装着靴による歩 行後の足部血流改善効果を検証し，現在実施している臨床态用 について報告する．
\end{abstract}

\section{2. 方法}

健常女性 11 名(20 歳から 37 歳 平均 22.4 歳)で測定した. 使 用する靴はウォーターインソールを装着したムーンスター社製の 試作靴を使用し，血流測定はドプラ血流計(OMEGAWAVE 社製) にて行った.ドプラ血流計は測定部位の動きによるノイズ出現お よびセンサーのずれが多く，動作による影響の少ない第一趾尖で 行うこととした. ウォーターインソール装着靴，非装着靴で安静を 4 分, 立位を 1 分, 歩行 $(3 \mathrm{~km} / \mathrm{h})$ を 4 分間実施し, その後安静時間 を5 分おいた.この間の足部血流の変化をドプラ血流計にて測定 し血流を比較した.

\section{3. 結果}

ウォーターインソール装着靴群は, 非装着靴群と比較して歩行 時, 歩行後の足部血流が増加していた. さらに歩行後血流を 30 秒ごとに区切り比較すると, 歩行後 30 秒以降でウォーターインソ 一ル装着靴群の皮膚血流が, 非装着靴群の皮膚血流と比較し有 意に増加していた(図1, 図2).

被験者に対してインソール装着靴と非装着靴の使用感と温熱 感をVAS スケールにて聴取したところ, 平均値ではウォーターイ ンソール装着靴が高い值をとったが, 有意差は見られなかった。

\section{4. 考察}

ウォーターインソールは堰とオリフィスで流れをコントロールする ことにより, 歩行に伴って衝撃吸収が必要な場所に水を流し, か つ衝撃吸収が必要な部分に水をためることができる構造になって いる.また、立脚相に水が踵部から足尖部に移動することによっ て, 足底マッサージ効果が得られる. 被験者からはこれまでもマッ サージ効果や温熱感があるとの感想が得られていた。

これまでの報告より 3), 足底マッサージ効果による連動後の皮 虐血流増加効果があることが認められていたが, 今回さらに歩行 中の血流増加効果も確認された.

歩行後の血流増加が 30 秒間は有意差がなかった原因として は, 歩行後の動作によってドプラ血流計がノイズを拾ってしまった 可能性がある.

本インソールの臨床応用として

・足部潰瘍のリスクがある糖尿病患者

糖尿病における足部潰瘍の発生率は高く 3,4$)$, 本インソー ルの使用によって潰瘍発生リスクを減少させる可能性がある. ・冷え性を自覚する患者

椧え性を自覚する患者では足部皮膚血流が低下することが指 摘されている5). 本インソールの血流改善効果によって自覚症状
を改善できる可能性がある.

今回の実験では，被験者を全て女性とした。以上のように良好 な結果を得たことで, 女性に多い冷え性への臨床応用が期待で きる.

\section{5. 結語}

ウォーターインソール装着靴による皮膚血流変化について報 告した. ウォーターインソールにより, 歩行時, 歩行後の足部皮膚 血流は增加した。

\section{6. 考支献}

1）森田信義，他, 衝撃吸収に優れたウォーターインソールの 開発, 福祉工学シンポジウム $2005,2005$.

2）入澤寛, 他, ウォーターインソール使用後の足部血流の変 化, 生活支援工学系連合大会 $2007,2007$.

3) Haris M. Rathur, Andrew J. M. Boulton, The Diabetic Foot, Clinics in Dermatology 2007; 25: 105-120.

4）渥美義仁, 糖尿病の足病変とケア, MEDICAL REHABILITATION 2004;47:52-57.

5) 後山尚久, 冷え性の病態の臨床的解析と対応, 医学のあ ゆみ 2005;215(11):925-929.

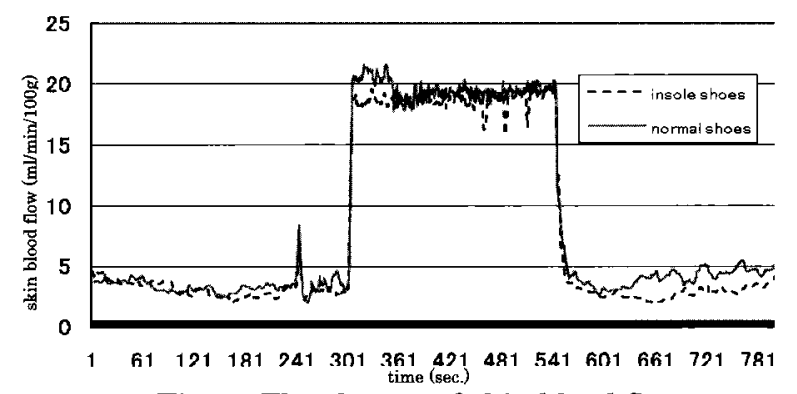

Fig. 1 The change of skin blood flow

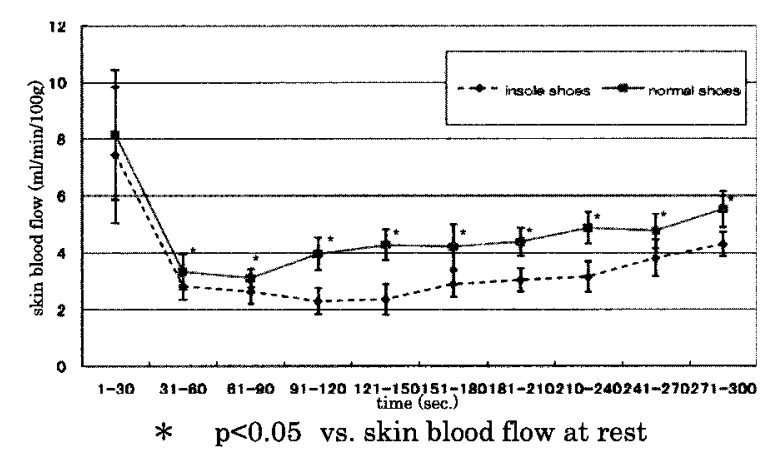

Fig. 2 The change of skin blood flow after walking 